\title{
Response of some Commercial Strawberry Cultivars to Infection by Wilt Diseases in Egypt and their Control with Fungicides
}

\section{T.A.A. Essa}

Plant Pathol. Res. Inst., A.R.C., Giza, Egypt.

Tsolation trials carried out from naturally infected strawberry plants Iby wilt diseases grown in three Counties at Qalubiya Governorate resulted in the presence of four fungi with different frequencies. These fungi were identified as Fusarium oxysporum, Verticillium dahliae, Rhizoctonia solani and Pythium sp. Pathogenicity test using the four fungi showed that only $F$. oxysporum and $V$. dahliae were able to cause the typical symptoms of wilt. Evaluation of six strawberry cultivars against $F$. oxysporum and $V$. dahliae under greenhouse conditions revealed that cvs. Festival, Florida and Sweet Charlie were less susceptible. While under field conditions they exhibited low percentages of final disease severity and low values of area under disease progress curve (AUDPC), low values of relative area under disease progress curve (rAUDPC) and low rates of infection (r-values) during the two tested growing seasons of 2010/11 and 2011/12. On the other hand, cvs. Fortuna and Camarosa exhibited the opposite results in this respect. Six fungicides were evaluated on the susceptible cv. Camarosa under greenhouse conditions and for two successive seasons under field conditions (2011/12 and 2012/13) where the most effective fungicides were Uniform, Tachigaren and Topsin- $M$ in controlling wilt infection. The highest yield increase percentage was recorded in cv. Camarosa during the two growing seasons (2012/13 and 2013/14) under protective trial by Uniform fungicide.

Keywords: Cultivars, fungicides, Fusarium oxysporum, strawberry, Verticillium dahliae and wilt.

Strawberry (Fragaria ananassa) is one of the most economically important berry crops in the world, with production of approximately 3.9 million tons. Egypt is the fourth largest producer of strawberries in the world where its productivity reached 240,000 tones (Anonymous, 2007).

Verticillium wilt, caused by the soilborne fungus Verticillium dahliae, is a worldwide disease affecting temperate and subtropical regions (Harris, 1989). This fungus causes vascular wilt in numerous Rosaceae hosts especially on strawberry (Wilhelm and Paulus, 1980).

The pathogenic fungi, i.e. Fusarium oxysporum f.sp. fragariae and V. dahliae form now serious problems for strawberry sustainable production under continuous cropping (Wang et al., 2007). Fusarium oxysporum infects host plants by penetrating plants through roots and it is responsible of severe damage and yield losses on many economically important plant species (Michielse and Rep, 2009). Fusarium oxysporum f.sp. fragariae causes rapid wilting and death of strawberry plants and severe economic losses worldwide (Fang et al., 2012a). Under controlled 
conditions, cv. Festival was the most resistant while cv. Camarosa was the most susceptible one to wilt infection caused by F. oxysporum (Fang et al., 2012a). Management of Fusarium wilt infection is mainly through chemical soil fumigation and resistant cultivars. The broad spectrum biocides are used to fumigate soil before planting, particularly methyl bromide (Fravel et al., 2003).

The aim of this research is an attempt to study the resistance or susceptibility of some strawberry cultivars against two fungi responsible to cause wilt under greenhouse and field conditions in Egypt. Moreover, evaluating the ability of some fungicides to control these wilt diseases will be taken into consideration.

\section{Materials and Methods}

All laboratory and greenhouse trials were carried out at Vegetable Dis. Res. Dept., Plant Pathol. Res. Inst., Agric. Res. Centre, Giza, Egypt. Six strawberry cultivars, i.e. Winter Dawn, Festival, Fortuna, Camarosa, Florida and Sweet Charlie, obtained from the Hort. Res. Inst., ARC, were used in this study.

\section{Isolation and identification of associated fungi:}

Samples of wilted strawberry plants were collected from some farms located in El-Khanka, Tokh and Shibin Al-Qanater Counties, Qalubiya Governorate, Egypt. The infected roots and crowns were firstly washed under running tap water, air dried, surface disinfected by dipping in $1 \%$ sodium hypochlorite solution for 3 minutes, washed several times with sterilized distilled water and dried between two folds of sterilized filter papers. The sterilized samples were cut out into small fragments and aseptically transferred onto Potato dextrose agar medium (PDA) into Petri plates. Inoculated Petri plates incubated at $25 \pm 2{ }^{\circ} \mathrm{C}$ and examined periodically. The emerged fungi picked up and transferred onto new PDA medium. Purification of each isolated fungus carried out using the hyphal tip technique (Hawker, 1956). Identification of the isolated fungi carried out according to their cultural and morphological characteristics as described by Gilman (1957), Barnett and Hunter (1987) and Leslie and Summerell (2006). Identification was confirmed in Mycological Research and Disease Survey Department, Agricultural Research Centre (ARC), Giza, Egypt. Frequencies of the isolated fungi were counted. Stock cultures maintained on PDA slants and kept at $5^{\circ} \mathrm{C}$ for further studies.

\section{Pathogenicity test:}

For inoculum preparation, each fungus was allowed to grow on corn meal sand medium (CMS) supplemented with $0.2 \%$ peptone for 8 days at $24^{\circ} \mathrm{C}$. Plastic pots (20 cm diameter) were sterilized by dipping in 5\% formalin solution for $5 \mathrm{~min}$ and left for air drying. Sand clay soil (1:1, v/v) was disinfected using $5 \%$ formalin. Plastic pots filled with approximately $3.0 \mathrm{~kg}$ of sterilized soil supplemented with $10 \mathrm{~g}$ of corn meal sand medium containing any of Fusarium oxysporum, Rhizoctonia solani, Verticillium dahliae and Pythium sp. (Abd El-Moity, 1985 and Ahmed, 2005). Soil infestation was achieved 10 days before transplanting. Strawberry transplants cv. Camarosa were evaluated in pots filled with infested or non-infested (check) soil at the rate of one transplant/pot. Five pots were used as one replicate and three replicates were used for each particular treatment. Reisolation from infected plants was carried out.

Egypt. J. Phytopathol., Vol. 43, No. 1-2 (2015) 
Disease assessments:

Disease incidence was estimated using the following equation:

$$
\text { Disease incidence }(\%)=\frac{\text { Number of infected plants }}{\text { Total number of plants }}
$$

Wilt severity was estimated 30 days post transplanting using a rating scale of $(0-5)$ based on stunted and leaf yellowing grading as mentioned by Fang et al. (2011b), where: $0=$ the plant well developed, no disease symptoms; $1=$ the plant slightly stunted; $2=$ the plant stunted and yellowing; $3=$ the plant severely stunted and wilting; 4 = majority of leaves of the plant wilted or dead; $5=$ plant dead.

Disease severity (DS \%) was estimated using the following equation as described by Liu et al. $(1995): \quad \operatorname{DS}(\%)=\Sigma \mathrm{d} /(\mathrm{d} \max \times \mathrm{n}) \times 100$.

Whereas: (d) is the disease rating of each plant, ( $\mathrm{d}$ max) is the maximum disease rating and (n) represents the total number of plants tested in each replicate.

3. Evaluation of some commercial strawberry cultivars:

a. Under greenhouse conditions:

Six commercial cultivars of strawberry, i.e. Winter Dawn, Festival, Fortuna, Camarosa, Florida and Sweet Charlie were used in this trail. Plants were transplanted in plastic pots $(20 \mathrm{~cm}$ in diameter) filled with about $3.0 \mathrm{~kg}$ sterilized soil then infested with $10 \mathrm{~g}$ of corn meal sand (CMS) medium containing any of $F$. oxysporum or $V$. dahliae inocula. The trial was carried out under greenhouse conditions. Five transplants were transplanted, each in a pot to serve as one replicate and three replicates represented each particular treatment. The pots were irrigated and fertilized when necessary. Wilt severity was estimated 30 days after planting using the formula described by Liu et al. (1995).

b. Under naturally infested field conditions:

The same six commercial strawberry cultivars which were used in the previous trial were also evaluated under field conditions at Shibin Al-Qanater County, Qalubiya Governorate, during two successive seasons of 2010/11 and 2011/12. On $15^{\text {th }}$ of September, fresh strawberry transplants were planted at $25-\mathrm{cm}$-apart of the same line on four lines of the prepared broad rows, each row $4 \mathrm{~m}$ long and $1 \mathrm{~m}$ wide (under dropping irrigation system) in complete randomized block design. Three plots were served as replicates for each treatment where each plot $(2.5 \times 4 \mathrm{~m})$ consisted of two rows.

Disease severity (\%) was recorded 30 days post transplanting for six times, every 7 days interval during the two successive seasons as mentioned before. The obtained data served in the determination of final disease severity, area under disease progress curve (AUDPC), Relative Area under disease progress curve (rAUDPC) and rate of infection (r-value). Area under disease progress curve (AUDPC) was estimated to compare different responses of the tested cultivars according to Pandey et al. (1989) using the following equation: $\mathrm{AUDPC}=\mathrm{D}[1 / 2(\mathrm{Y} 1+\mathrm{YK})+\mathrm{Y} 2+\mathrm{Y} 3+\ldots . \mathrm{Y}(\mathrm{K}-1)]$ Where: $\mathrm{D}=$ days between readings, $\mathrm{Y} 1=$ first disease record, $\mathrm{Yk}=$ last disease record. 
Relative area under disease progress curve (rAUDPC) was performed according to Milus and Line (1986) as follows:

$$
\text { rAUDPC= }=\frac{\text { Line AUDPC }}{\text { Susceptible AUDPC }}
$$

Rate of infection (r-value), was also estimated as a function of time to determine the ability of the tested genotype to affect the development of infection under field conditions. It was calculated from the different scores as a severity of infection at the time of appearance and each seven days interval thereafter. Thus, r-value was estimated according to Van der Plank (1963) using the following equation:

$$
\text { R-value }=\frac{1}{t_{2}-t_{1}}\left(\log _{\mathrm{e}} \frac{\mathrm{X}_{2}}{1-\mathrm{X}_{2}}-\log _{\mathrm{e}} \frac{\mathrm{X}_{1}}{1-\mathrm{X}_{1}}\right)
$$

Whereas: $\mathrm{X} 1=\mathrm{DS}(\%)$ at t1date.

$\mathrm{X} 2=\mathrm{DS}(\%)$ at $\mathrm{t} 2$ date.

$\mathrm{t} 2-\mathrm{t} 1=$ Time interval in days between two observations.

4. Efficacy of fungicides against strawberry wilt diseases:

a) Under greenhouse conditions:

Camarosa cultivar was selected for this trail because of its clear sensitivity to Fusarium and Verticillium wilt diseases. Transplants were transplanted in pots as previously described, at the rate of one plant/pot. Five pots served as one replicate and three replicates were used for each particular treatment. Three replicates of untreated soil were used as check. Fifteen days after transplanting, six fungicides were applied as soil drench at 7 days interval for three times. The application was carried out at the proper time and doses were applied as mentioned in Table (1).

Table 1. Six commercial fungicides assigned for strawberry wilt management

\begin{tabular}{|c|l|l|c|}
\hline No. & \multicolumn{1}{|c|}{ Common name } & Brand name & Tested dose/l \\
\hline 1 & Carbendazium & Carbendazim & $2 \mathrm{gm}$ \\
\hline 2 & Tolclofos-methyl & Rizolex-T & $2 \mathrm{gm}$ \\
\hline 3 & Hymexazol & Tachigaren & $2 \mathrm{ml}$ \\
\hline 4 & Mefenoxam and Azoxystrobin & Uniform & $2 \mathrm{ml}$ \\
\hline 5 & Thiophanate methyl & Topsin-M & $1.5 \mathrm{gm}$ \\
\hline 6 & Propamocarb hydrochloride & Previcur & $2.5 \mathrm{ml}$ \\
\hline
\end{tabular}

b) Under naturally infested field conditions:

The same six fungicides were evaluated under naturally infested field conditions. This experiment was conducted in Shibin Al-Qanater County, Qalubiya Governorate, during 2011/12 - 2012/13 growing seasons.

A complete block randomized design with 3 replications was adopted in this respect. The cultivar Camarosa was selected for this experiment on the basis of its 
susceptibility for wilt diseases. The experimental unit was a plot measured $2.5 \times 4.0 \mathrm{~m}^{2}$ consisted of 2 rows with $4 \mathrm{~m}$ long. All cultural practices were applied according to the technical recommendation of the crop as normal. The first symptom was observed after 30 days from planting date, i.e. $10^{\text {th }}$ of October. The treatments were applied at 7 days interval. The application was carried out at the proper time and the doses were applied according to Table (1). Disease severity (DS \%) was recorded after 60 days as previously described. Efficacy of each fungicide was computed according to the following formula adopted by Mahmoud et al. (2013).

Efficacy $(\%)=\frac{\text { DS }(\%) \text { in check treatment - DS }(\%) \text { in fungicide treatment }}{\text { DS }(\%) \text { in check treatment }} \times 100$

5. Assessment of yield increase of strawberry cultivars due to application of Uniform fungicide:

The previously mentioned commercial strawberry cultivars were evaluated under field conditions for two successive seasons (2012/2013 and 2013/2014) for their yields as a result of using the fungicide Uniform. Each cultivar was transplanted on two plots, one protected from natural wilt diseases using Uniform fungicide as soil drench and the other one is unprotected. The treatments were applied after 30 days post planting date at 7 days interval for three times. The application was carried out using the doses shown in Table (1). The yielded fruits of each plot were weighted from $15^{\text {th }}$ November till the end of February and were calculated per plot and then per feddan.

Yield increase percentage:

Yield increase was estimated as following:

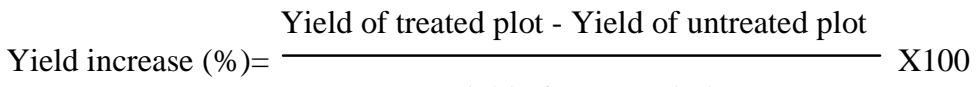

Yield of untreated plot

Statistical analysis:

Data were analyzed using analysis of variance one way (ANOVA), and the means were compared by the least significant difference (LSD) at $\mathrm{P} \geq 0.05$ as described by Snedecor and Cochran (1980).

\section{R e s u l t s}

\section{Isolation and identification of the associated fungi}

Data illustrated in Table (2) show that 7 fungal species belonging to 7 genera were isolated from wilted roots and crowns of strawberry plants collected from the three Counties, i.e. El-Khanka, Tokh and Shibin Al-Qanater, Qalubiya Governorate. These fungi were identified as Fusarium oxysporum Schlecht, F. solani Mart. Apple and Wollerweb, Verticillium dahliae Klebahn, Macrophomina phaseolina (Tassi) Goid, Rhizoctonia solani Kuhn, Pythium sp. Pringsheim and Phoma sp. Data also show that Fusarium oxysporum and $V$. dahliae showed the highest frequency, being 29.3 and $21.95 \%$, respectively. On the other hand, R. solani and Pythium sp. 
Table 2. Frequency percentage of fungi isolated from wilted strawberry plants collected from Qalubiya Governorate

\begin{tabular}{|l|c|c|c|c|c|c|c|c|}
\hline \multirow{2}{*}{$\begin{array}{c}\text { Isolated } \\
\text { fungus }\end{array}$} & \multicolumn{2}{|c|}{ El-Khanka } & \multicolumn{2}{|c|}{ Tokh } & \multicolumn{2}{c|}{ Shibin Al-Qanater } & \multicolumn{2}{c|}{ Total } \\
\cline { 2 - 10 } & No.* & $\begin{array}{c}\text { Frequency } \\
(\%)\end{array}$ & No. & $\begin{array}{c}\text { Frequency } \\
(\%)\end{array}$ & No. & $\begin{array}{c}\text { Frequency } \\
(\%)\end{array}$ & No. & $\begin{array}{c}\text { Frequency } \\
(\%)\end{array}$ \\
\hline F. oxysporum & 1 & 9.1 & 3 & 30.0 & 8 & 40.0 & 12 & 29.3 \\
\hline F. solani & 2 & 18.2 & 0 & 0.0 & 1 & 5.0 & 3 & 7.3 \\
\hline V. dahliae & 3 & 27.3 & 1 & 10.0 & 5 & 25.0 & 9 & 21.9 \\
\hline M. phaseolina & 0 & 0.0 & 2 & 20.0 & 1 & 5.0 & 3 & 7.3 \\
\hline R. solani & 2 & 18.2 & 2 & 20.0 & 2 & 10.0 & 6 & 14.6 \\
\hline Pythium sp. & 1 & 9.1 & 1 & 10.0 & 3 & 15.0 & 5 & 12.2 \\
\hline Phoma sp. & 2 & 18.2 & 1 & 10.0 & 0 & 0.0 & 3 & 7.3 \\
\hline \multicolumn{1}{|c|}{ Total } & 11 & 100 & 10 & 100 & 20 & 100 & 41 & 100 \\
\hline
\end{tabular}

No. $=$ Number of isolates.

showed moderate frequency, being 14.6 and $12.2 \%$, respectively. While $F$. solani, M. phaseolina and Phoma sp. had less frequency with $7.3 \%$ for each fungus. Accordingly, $F$. oxysporum and $V$. dahliae isolated from Shibin Al-Qanater, $R$. solani isolated from El-Khanka and Pythium sp. isolated from Tokh were selected to determine their pathogenic capabilities.

\section{Pathogenicity test.}

Data presented in Table (3) reveal that $F$. oxysporum and $V$. dahliae showed the highest disease incidence, being 86.7 and $93.3 \%$ and disease severity 58.2 and $58.0 \%$ respectively. On the other hand, wilt symptoms did not appear due to the artificial inoculation by $R$. solani and Pythium sp.

Table 3. Pathogenicity test of fungi isolated from roots and crowns of wilted strawberry plants collected from Qalubiya Governorate

\begin{tabular}{|l|c|c|}
\hline \multicolumn{1}{|c|}{ Isolated fungus } & Disease incidence (\%) & Disease severity (\%) \\
\hline Fusarium oxysporum & 86.7 & 58.2 \\
\hline Rhizoctonia solani & 00.0 & 0.0 \\
\hline Verticillium dahliae & 93.3 & 58.0 \\
\hline Pythium sp. & 0.0 & 0.0 \\
\hline Check & 0.0 & 0.0 \\
\hline L.S.D at 0.05 & 21.2 & 2.0 \\
\hline
\end{tabular}

III. Evaluation of commercial strawberry cultivars to wilt diseases:

a- Under greenhouse conditions:

Data presented in Table (4) show the disease severity values on six commercial strawberry cultivars against two wilt fungi ( $F$. oxysporum and $V$. dahliae) under greenhouse conditions. In this respect, cvs. Festival and Sweet Charlie were less susceptible to Verticillium wilt where the recorded disease severity values were 12.0 and $25.3 \%$, respectively. On the other hand, cvs. Fortuna and Camarosa were highly susceptible where the scored disease severity values were 62.7 and $58.7 \%$,

Egypt. J. Phytopathol., Vol. 43, No. 1-2 (2015) 
Table 4. Reaction of six commercial strawberry cultivars to wilt infection under greenhouse conditions

\begin{tabular}{|l|c|c|}
\hline \multirow{2}{*}{\multicolumn{1}{|c|}{ Tested cultivar }} & \multicolumn{2}{c|}{ Disease severity (\%) } \\
\cline { 2 - 3 } & V. dahliae & F. oxysporum \\
\hline Festival & 12.0 & 34.6 \\
\hline Winter Dawn & 44.0 & 52.0 \\
\hline Fortuna & 62.7 & 40.0 \\
\hline Florida & 49.3 & 29.3 \\
\hline Sweet Charlie & 25.3 & 50.7 \\
\hline Camarosa & 58.7 & 53.3 \\
\hline \multicolumn{1}{|c|}{ L.S.D at 0.05} & 5.4 & 3.6 \\
\hline
\end{tabular}

respectively. As for Fusarium wilt, cvs. Florida and Festival recorded the low DS\% if compared with the other tested cultivars, being 29.3 and $34.6 \%$, respectively. While, cvs. Camarosa and Winter Dawn were highly susceptible to Fusarium wilt where the recorded DS percentages were 53.3 and $52.7 \%$, respectively.

\section{$b$ - Under naturally infested field conditions:}

Disease severity percentages due to infection by wilt on 6 commercial strawberry cultivars were recorded starting from the first appearance of wilt symptoms on plants. Three epidemiological parameters, i.e. disease severity (\%), area under disease progress curve (AUDPC) and rate of disease increase (r-value), were estimated.

As for the first growing season 2010/11, data presented in Table (5) show that Festival, Florida and Sweet Charlie cultivars exhibited low percentages of final disease severity, low values of AUDPC, low values of rAUDPC and low rates of disease infection (r-values) where the recorded data on the three cultivars were 8.3, 255.5, 0.53 and 0.019 for cv. Festival; 8.8, 302.5, 0.63 and 0.021 for cv. Florida and 9.6, 288.0, 0.60 and 0.020 for cv. Sweet Charlie, respectively. However, cvs. Fortuna and Camarosa exhibited high percentages of disease severity, and high values of AUDPC, high values of rAUDPC and high rates of r-values where the recorded data were 15.8, 480.0, 0.99 and0.025 for cv. Fortuna and 13.3, 483.5, 1.00 and 0.0250 for cv. Camarosa, receptively.

Table 5. Evaluation of commercial strawberry cultivars to infection by wilt under natural field conditions during season 2010/11

\begin{tabular}{|c|c|c|c|c|c|c|c|c|c|}
\hline \multirow[t]{2}{*}{ Cultivar } & \multicolumn{6}{|c|}{$\begin{array}{c}\text { Disease severity (\%) after transplanting } \\
\text { (days) }\end{array}$} & \multirow[t]{2}{*}{ AUDPC } & \multirow[t]{2}{*}{ rAUDPC } & \multirow[t]{2}{*}{ r-value } \\
\hline & 30 & 37 & 42 & 49 & 56 & 63 & & & \\
\hline Festival & 3.4 & 3.6 & 3.6 & 5.0 & 7.50 & 8.3 & 255.5 & 0.528 & 0.0189 \\
\hline Winter Dawn & 3.3 & 3.8 & 5.0 & 7.9 & 9.60 & 10.4 & 331.5 & 0.686 & 0.0245 \\
\hline Fortuna & 5.2 & 5.4 & 7.1 & 10.8 & 14.20 & 15.8 & 480.0 & 0.993 & 0.0246 \\
\hline Florida & 3.3 & 4.6 & 5.4 & 6.7 & 7.50 & 8.8 & 302.5 & 0.626 & 0.0208 \\
\hline Sweet Charlie & 3.8 & 4.2 & 5.0 & 5.8 & 7.10 & 9.6 & 288.0 & 0.596 & 0.0198 \\
\hline Camarosa & 4.2 & 7.5 & 10.0 & 10.4 & 11.70 & 13.3 & 483.5 & 1.000 & 0.0250 \\
\hline L.S.D at 0.05 & 0.31 & 0.3 & 0.4 & 0.6 & 0.4 & 0.2 & 12.5 & --- & --- \\
\hline
\end{tabular}


Concerning the second growing season (2011/12), data in Table (6) show that the low percentages of disease severity, low values of AUDPC and low values of rAUDPC as well as low rates of r-values were recorded for cv. Festival (8.9, 260.5, 0.548 and 0.020); cv. Florida $(9.4,313.5,0.660$ and 0.024) and cv. Sweet Charlie $(10.2,296.0,0.623$ and 0.021$)$, respectively. On the other hand, the high percentages of final disease severity, high values of AUDPC, high values of rAUDPC and high rates of r-values were recorded for cv. Fortuna $(16.4,458.5,0.965$ and 0.025$)$ and cv. Camarosa (14.4, 475.0,1.000 and 0.027), respectively. Moreover, cvs. Festival, Florida and Sweet Charlie were the less susceptible cultivars to wilt infection during the two growing seasons 2010/11 and 2011/12.

Table 6. Evaluation of commercial strawberry cultivars to infection by wilt under natural field conditions during season 2011/12

\begin{tabular}{|l|c|c|c|c|c|c|c|c|c|}
\hline \multirow{2}{*}{ Cultivar } & \multicolumn{6}{|c|}{ Disease severity (\%) after transplanting } & \multirow{2}{*}{ AUDPC } & \multirow{2}{*}{ rAUDPC } & \multirow{2}{*}{ r-value } \\
\cline { 2 - 9 } & 30 & 37 & 42 & 49 & 56 & 63 & & & \\
\hline Festival & 3.40 & 3.4 & 4.1 & 5.5 & 6.9 & 8.9 & 260.5 & 0.548 & 0.02 \\
\hline Winter Dawn & 3.60 & 4.0 & 5.7 & 8.4 & 9.0 & 11.0 & 344.0 & 0.724 & 0.02 \\
\hline Fortuna & 5.30 & 5.6 & 6.7 & 10.3 & 12.4 & 16.4 & 458.5 & 0.965 & 0.02 \\
\hline Florida & 3.10 & 4.8 & 5.0 & 7.2 & 8.1 & 9.4 & 313.5 & 0.660 & 0.02 \\
\hline Sweet Charlie & 3.80 & 4.4 & 4.6 & 6.3 & 7.3 & 10.2 & 296.0 & 0.623 & 0.02 \\
\hline Camarosa & 4.20 & 7.7 & 8.5 & 10.9 & 11.1 & 14.4 & 475.0 & 1.000 & 0.03 \\
\hline L.S.D at0.05 & 0.21 & 0.35 & 0.38 & 0.34 & 0.42 & 0.39 & 11.62 & --- & -- \\
\hline
\end{tabular}

IV. Efficacy of fungicides against strawberry wilt diseases:

a- Under greenhouse conditions:

Six fungicides were evaluated against $V$. dahliae and $F$. oxysporum on the susceptible cultivar Camarosa under greenhouse and field conditions compared to check treatment. As for $V$. dahliae infection, the fungicide Uniform followed by Tachigaren, Topsin- $M$ and Carbendazim were the most effective fungicides on disease incidence and disease severity without significant difference among them under greenhouse conditions. Meanwhile, Rizolex-T was the least effective one in this respect in case of $V$. dahliae. The same trend was also noticed in case of F. oxysporum (Table 7).

Table 7. Effect of six tested fungicides on the infection of strawberry (cv. Camarosa) by wilt under greenhouse conditions

\begin{tabular}{|l|c|c|c|c|}
\hline \multirow{2}{*}{$\begin{array}{c}\text { Tested } \\
\text { fungicide }\end{array}$} & \multicolumn{2}{c|}{ V. dahliae } & \multicolumn{2}{c|}{ F. oxysporum } \\
\cline { 2 - 5 } & Disease incidence & Disease Severity & Disease Incidence & Disease Severity \\
\hline Carbendazim & 13.3 & 9.5 & 11.1 & 8.7 \\
\hline Rizolex-T & 24.4 & 12.3 & 31.1 & 12.5 \\
\hline Topsin-M & 15.5 & 8.6 & 19.9 & 7.5 \\
\hline Previcur-N & 22.2 & 7.4 & 19.9 & 10.0 \\
\hline Uniform & 6.3 & 2.8 & 6.6 & 0.8 \\
\hline Tachigaren & 8.8 & 5.0 & 6.6 & 5.0 \\
\hline Check & 66.6 & 58.7 & 68.8 & 53.3 \\
\hline L.S.D at0.05 & 8.5 & 6.2 & 12.3 & 5.9 \\
\hline
\end{tabular}

Egypt. J. Phytopathol., Vol. 43, No. 1-2 (2015) 


\section{b- Under naturally infested field conditions:}

In this respect, data in Table (8) show that the most effective fungicides were Uniform, Tachigaren and Topsin-M without significant differences among them during the two growing seasons On the other hand, the least effective fungicide was Rizolex-T during the two growing seasons.

Table 8. Effect of six fungicides on strawberry wilt infection (cv. Camarosa) under field conditions during seasons 2011/12 and 2012/13

\begin{tabular}{|l|c|c|c|c|}
\hline \multirow{2}{*}{ Fungicide } & \multicolumn{4}{|c|}{ Growing season } \\
\cline { 2 - 5 } & \multicolumn{2}{|c|}{$2011 / 12$} & \multicolumn{2}{c|}{$2012 / 13$} \\
\cline { 2 - 5 } & $\begin{array}{c}\text { Disease } \\
\text { severity }\end{array}$ & $\begin{array}{c}\text { Effectiveness } \\
(\%)\end{array}$ & $\begin{array}{c}\text { Disease } \\
\text { severity }\end{array}$ & $\begin{array}{c}\text { Effectiveness } \\
(\%)\end{array}$ \\
\hline Carbendazim & 8.2 & 56.6 & 7.1 & 63.2 \\
\hline Rizolex-T & 9.1 & 51.5 & 8.2 & 57.5 \\
\hline Topsin-M & 6.2 & 67.3 & 4.9 & 75.0 \\
\hline Previcur-N & 8.6 & 54.5 & 7.2 & 62.7 \\
\hline Uniform & 4.9 & 74.1 & 4.4 & 77.2 \\
\hline Tachigaren & 5.4 & 71.2 & 5.1 & 73.6 \\
\hline Check & 18.8 & ---- & 19.4 & --- \\
\hline L.S.D at 0.05 & 4.28 & & 3.96 & \\
\hline
\end{tabular}

$V$ - Assessment of yield increase of strawberry cultivars due to application of Uniform fungicide:

The trail aimed to study the productivity of infected and protected six strawberry cultivars $(\mathrm{kg} / \mathrm{plot}$ and ton/feddan) grown in the field under natural soil infestation with the causal pathogens of wilt diseases. The tested cultivars were grown at Shibin Al-Qanater County, Qalubiya Governorate, during two successive seasons of 2011/12 and 2012/13.

Data in Table (9) indicate that treating soil with Uniform fungicide resulted in great increases in fruit yield of all tested cultivars in comparison with those planted in naturally infested soil. Data also show that the least yield increase percentage as $\mathrm{kg} / \mathrm{plot}$ was recorded in case of $\mathrm{cv}$. Florida, being 23.3 and 41.6 during the two growing seasons (2011/12 and 2012/13), respectively. On the other hand, the highest yield increase percentage during the same two growing seasons was recorded in case of cv. Camarosa as kg/plot, being 57.7 and 73.2, respectively. 
Table 9. Yield increase percentage of infected and protected by uniform fungicide strawberry cultivars under field conditions (naturally infested by wilt diseases) during 2012/13 and 2013/14 growing seasons at Qalubiya Governorate

\begin{tabular}{|c|c|c|c|c|c|c|}
\hline \multirow[b]{3}{*}{ Tested cultivar } & \multicolumn{6}{|c|}{ Yield (kg/plot) } \\
\hline & \multicolumn{3}{|c|}{$2012 / 13$} & \multicolumn{3}{|c|}{$2013 / 14$} \\
\hline & 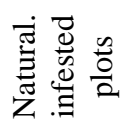 & 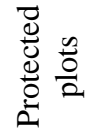 & $\begin{array}{c}\text { Yield } \\
\text { Increase } \\
(\%)\end{array}$ & 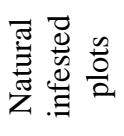 & $\begin{array}{l}\overrightarrow{0} \\
\frac{0}{0} \\
\frac{0}{0} \\
0\end{array}$ & $\begin{array}{c}\text { Yield } \\
\text { Increase } \\
(\%)\end{array}$ \\
\hline Festival & 29.2 & 37.8 & 29.5 & 25.8 & 39.8 & 54.0 \\
\hline Winter Dawn & 23.9 & 33.3 & 39.0 & 22.7 & 34.4 & 51.5 \\
\hline Fortuna & 23.9 & 34.5 & 44.5 & 23,5 & 35.8 & 52.7 \\
\hline Florida & 26.9 & 33.1 & 23.3 & 24.2 & 34.2 & 41.6 \\
\hline Sweet Charlie & 28.3 & 38.6 & 36.2 & 25.1 & 39.2 & 56.2 \\
\hline Camarosa & 22.6 & 35.6 & 57.7 & 21.6 & 37.4 & 73.2 \\
\hline L.S.D. (0.05) & 2.65 & 1.88 & 8.21 & 1.32 & 2.41 & 5.46 \\
\hline
\end{tabular}

\section{D i s c us s i o n}

Fusarium oxysporum Schlecht, Rhizoctonia solani Kuhn, Verticillium dahliae Klebahn and Pythium sp. were isolated from the roots and crowns of diseased strawberry plants collected from some Farms located at El-Khanka, Tokh and Shibin Al-Qanater Counties, Qalubiya Governorate. Results indicated that F. oxysporum and $V$. dahliae were able to cause wilt diseases of the tested strawberry cultivars. These results of the pathogenicity test are confirmed by the findings of Sumino (1995) who found that $V$. dahliae was more widespread in strawberry in Hokkaido. Furthermore, in the absence of soil fumigation, crop rotation patterns may dictate the exposure of strawberries to strains of $V$. dahliae associated with other crops in the future (Gordon et al., 2006). Likewise, Abdel-Sattar et al. (2008); Zhao et al. (2009) and Suga et al. (2013) confirmed that $F$. oxysporum f.sp. fragariae was identified as the predominant pathogen in many countries in the world, the first recording of this was in western Australia (Phillips and Golzar, 2008). Also Williamson et al. (2012) reported that the main causal agent of strawberry wilt was $F$. oxysporum that isolated from crown and root in South Carolina. Several other studies indicated that $F$. oxysporum was among the major causal agents of strawberry wilting (Nagarajan et al., 2006 and Ebihara and Uematsu, 2014).

Presented study showed that strawberry cultivars vary in their responses to infection by different pathogens of wilt under greenhouse conditions. However, cv. Festival was the less susceptible to infection by the two-wilt fungi followed by cvs. Sweet Charlie and Florida under greenhouse conditions. However, cvs. Camarosa and Winter Dawn were more sensitive to infection by $F$. oxysporum. While, under field conditions; AUDPC, rAUDPC and r-values for the strawberry cultivars, indicated that cvs. Festival, Florida and Sweet Charlie exhibited low percentages of final disease severity, and low values of AUDPC, rAUDPC and low 
r-values. Whereas, cvs. Fortuna and Camarosa exhibited high percentages of final disease severity, and high values of AUDPC, rAUDPC and high rates of r-values. These results are in accordance with those reported by Redondo et al. (2009) who found that cv. Aguedilla was more resistant to $V$. dahliae than 'Camarosa. Fang et al. (2011 a and b) reported that cv. Festival was most resistant and cv. Camarosa most susceptible to $F$. oxysporum, which was the most important pathogen, particularly associated with crown disease. Pérez-Jiménez et al. (2012) found that cv. Sabrosa was classified as Verticillium resistant cultivar because its AUDPC was not significantly differed to that of 'Pandora', the Verticillium wiltresistant cultivar. Also, many researchers reported different varietal reactions against wilt, i.e. Jordan (1971); Govorova (1997); Shaw et al. (1997); Fang et al. (2012b) who found that Festival was resistant and Camarosa was susceptible to wilt.

In spite of the presence of some strawberry resistant cultivars, some farmers prefer growing the susceptible cultivars. Furthermore, recent trends tend to prevent using methyl Bromide gas because of the damage resulting, as well as high rates of methyl bromide alternatives. Therefore, we need to use some fungicides to control $V$. dahliae and $F$. oxysporum infection. Accordingly, six fungicides were evaluated on the susceptible cv. Camarosa under greenhouse and field conditions during two growing seasons, i.e. 2011/12 and 2012/13. In this respect, Uniform, Tachigaren, Topsin-M and Rizolex-T were the most effective. These results are similar to those obtained by Abou-Zeid et al. (1990), who found that Rizolex (Tolclofos-methyl) 50, Rizolex-T and Quinolate V4X were equally good against $F$. oxysporum and Verticillium sp. Harsh et al. (1992) and Tawil et al. (1992) evaluated Bavistin (carbendazim), Topsin-M (thiophanate-methyl) against Verticillium wilt. Ahmed et al. (1994) reported that Rizolex-T was the most effective fungicide; meanwhile Topsin-M and Monceren were less effective against $F$. oxysporum.

Cultivar Florida gave the least yield increment, represented as $\mathrm{kg} / \mathrm{plot}$ during the growing seasons of 2012/13 and 2013/14, respectively. On the other hand, cv. Camarosa gave the highest yield increment in the protected cultivation. Phillips and Golzar (2008) reported that strawberry cv. Camino Real still normally produces a higher proportion of marketable fruit than cv. Camarosa and is reputed to have resistance to Verticillium wilt, Phytophthora crown rot and Anthracnose crown rot.

\section{R e f e r e n c e s}

Abd El-Moity, T.H. 1985. Effect of single and mixture of Trichoderma harzianum isolates on controlling three different soil-borne pathogens. Egypt, J. Microbiol., Special Issue, 111-120.

Abdel-Sattar, M.A.; El-Marzoky H.A.; and Mohamed A.I. 2008. Occurrence of soil borne diseases and root knot nematodes in strawberry plants grown on compacted rice straw bales compared with naturally infested soil. J. Pl. Protect. Res., 48: 223-235.

Abou-Zeid, N.M.; El-Wakil, A.A.; El-Sherif, Ibtisam M. and Amer, M.I. 1990. Studies on root rot and wilt of lentil and their control. Agric. Res. Rev., 68(3): 471-479. 
Ahmed, K.G.M.; El-Said, S.I.A.; Fawzy, R.N.; Bader, A.E. and Abd-Allah, M.A. 1994. Pathological study on sunflower plants, chemical and biological control and seed oil content. Ann. Agric. Sci. Moshtohor, 32(3): 1529-1543.

Ahmed, M.F.A. 2005. Effect of Adding Some Biocontrol Agents on Non-target Microorganisms in Root Diseases Infecting Soybean and Broad Bean Plants. M.Sc. Thesis. Fac. Agric., Moshtohor, Benha Univ., 137 pp.

Anonymous, 2007. FAOSTAT Agricultural Statistics Database. http://www.Fao.org.

Barnett, H.J. and Hunter B.B. 1987. Illustrated Genera of Imperfect Fungi. Burgess Publ. Co., Minneapolis, USA, 218 pp.

Ebihara, Y. and Uematsu, S. 2014. Survival of strawberry-pathogenic fungi Fusarium oxysporum f.sp. fragariae, Phytophthora cactorum and Verticillium dahliae under anaerobic conditions. J. General Plant Pathol., 80: 50-58.

Fang, X.L.; Phillips, D.; Sivasithamparam, K. and Barbetti, M.J. 2011a. Severity of crown and root diseases of strawberry and associated fungal and Oomycete pathogens in Western Australia. Australasian Plant Pathol., 40: 109-119.

Fang, X.L.; Phillips D.; Sivasithamparam K. and Barbetti M.J. 2011b. Comparisons of virulence of pathogens associated with crown and root diseases of strawberry in Western Australia with special reference to the effect of temperature. Sci. Hort., 131: 39-48.

Fang, X.L.; Kuo J.; You M.P.; Finnegan P.M. and Barbetti M.J. 2012a. Comparative root colonisation of strawberry cultivars Camarosa and Festival by Fusarium oxysporum f.sp. fragariae. Plant Soil, 358: 75-89.

Fang, X.L.; Phillips, D.; Li, H.; Verheyen, G.; Sivasithamparam, K. and Barbetti M.J. 2012b. Yields and resistance of strawberry cultivars to crown and root diseases in the field, and variety responses to pathogens under controlled environment conditions. Phytopathologia Medit., 51(1): 69-84.

Fravel, D., Olivain, C. and Alabouvette, C. 2003. Fusarium oxysporum and its biocontrol. New Phytol., 157: 493-502.

Gilman, J.C. 1957. A Manual of Soil Fungi. $2^{\text {nd }}$ Ed. The Iowa State College Press, Ames, Iowa, USA, $450 \mathrm{pp}$.

Gordon, T.R.; Kirkpatrick, S.C.; Hansen, J. and Shaw, D.V. 2006. Response of strawberry genotypes to inoculation with isolates of Verticillium dahliae differing in host origin. Plant Pathol., 55: 766-769.

Govorova G.F. 1997. Phytopathological aspects of strawberry breeding for resistance to Verticillium wilt. Acta Hort., 439: 195-197.

Harris, D.C. 1989. Control of Verticillium wilt of strawberry in Britain by chemical soil disinfestation. J. Hort. Sci., 64: 683-686.

Harsh, N.S.K.; Dadwal, V.S. and Jamaluddin, N. 1992. A new post-emergence damping off disease of Eucalyptus seedlings. Indian Forester, 118(4): 279-283.

Egypt. J. Phytopathol., Vol. 43, No. 1-2 (2015) 
Hawker, L.E. 1956. Physiology of Fungi. Univ. of London Press, Ltd, War-Witch Square, London, $452 \mathrm{pp}$.

Jordan V.W.L. 1971. A method of screening strawberries for resistance to Verticillium wilt. Pl. Pathol., 20: 167-170.

Leslie, J.F. and Summerell, B.A. 2006. The Fusarium Laboratory Manual. Blackwell Pub. Ltd, London, UK, 388pp.

Liu, L.; Kloepper, J.W. and Tuzun, S. 1995. Introduction of systemic resistance in cucumber against Fusarium wilt by plant growth-promoting rhizobacteria. Phytopathology, 85: 695-698.

Mahmoud, E. Y.; Ibrahim M.M. and Essa T.A.A. 2013. Efficacy of plant essential oils in controlling damping-off and root rots diseases of peanut as fungicides alternative. J. Appl. Sci. Res., 9(3): 1612-1622.

Michielse, C.B. and Rep, M. 2009. Pathogen profile update: Fusarium oxysporum. Mole. Plant Pathol., 10: 311-324.

Milus, E.A. and Line R.F. 1986. Gene action for inheritance of durable, hightemperature, adult plant resistances to stripe rust in wheat. Phytopathology, 76: $435-441$.

Nagarajan, G.; Kang, S.W.; Nam, M.H.; Song, J.Y.; Yoo, S.J. and Kim, H.G. 2006. Characterization of Fusarium oxysporum f.sp. fragariae based on vegetative compatibility group, random amplified polymorphic DNA and pathogenicity. The Plant Pathol. J., 22: 222-229.

Pandey, H.N.; Menon, T.C.M. and Rao, M.V. 1989. A simple formula for calculating area under disease progress curve. Rachis, 8(2): 38-39.

Pérez-Jiménez, R.M.; De Cal, A.; Melgarejo, P.; Cubero, J.; Soria, C.; Zea-Bonilla, T. and Larena, I. 2012. Resistance of several strawberry cultivars against three different pathogens. Spanish J. Agric. Res., 10(2): 502-512.

Phillips, D. and Golzar, H. 2008. Strawberry root and crown rot disease survey 2005 and 2006 seasons. Bulletin No. 4747. Dept. of Agric. and Food, Western Australia.

Redondo, C.; De Cal, A.; Martínez-Treceño, A.; Becerril, M.; López-Aranda, J.M. and Melgarejo, P. 2009. Evaluation of resistance of several strawberry selections against main fungal pathogens. Acta Hort., 842: 211-214.

Shaw, D.V.; Gubler, W.D. and Hansen, J. 1997. Field resistance of California strawberries to Verticillium dahliae at three conidial inoculum concentrations. Hort. Sci., 32: 711-713.

Snedecor, G.W. and Cochran, W.G. 1980. Statistical Methods. $7^{\text {th }}$ Ed. Iowa State Univ. Press, Iowa, USA.

Suga, H.; Hirayama, Y.; Morishima, M.; Suzuki, T.; Kageyama, K. and Hyakumachi, M. 2013. Development of PCR primers to identify Fusarium oxysporum f.sp. fragariae. Plant Dis., 97: 619-625. 
Sumino, A. 1995. The present situation on research of Verticillium wilt of potato in Hokkaido (in Japanese). Plant Protect., 49: 500-505.

Tawil, M.H.; Hallak, H. and Abdin, M. 1992. Investigation on the behavior of benzimidazole fungicides in olive seedling after soil treatment. Arab J. Plant Protect., 10(2): 140-147.

Van der Plank, J.E. 1963. Plant Disease: Epidemics and Control. Academic Press, NY, USA.

Wang, L.; Tongle, H.U.; Lijing, J.I. and Keqiang, C.A.O. 2007. Inhibitory efficacy of calcium cyanamide on the pathogens of replant diseases in strawberry. Front. Agric. China, 1(2): 183-187.

Wilhelm, S. and Paulus, A.O. 1980. How soil fumigation benefits the California strawberry industry. Plant Dis., 64: 264-270.

Williamson, M. Fernández-Ortuño, D. and Schnabel, G. 2012. First report of Fusarium wilt of strawberry caused by Fusarium oxysporum in South Carolina. Plant Dis., 96: 911.

Zhao, X.H.; Zhen, W.C., Qi, Y.Z.; Liu, X.I. and Yin B.Z. 2009. Coordinated effects of root autotoxic substances and Fusarium oxysporum Schl. f.sp. fragariae on the growth and replant disease of strawberry. Front. Agric. China, 3: 34-39.

(Received 07/07/2015

in revised form 13/09/2015)

Egypt. J. Phytopathol., Vol. 43, No. 1-2 (2015) 


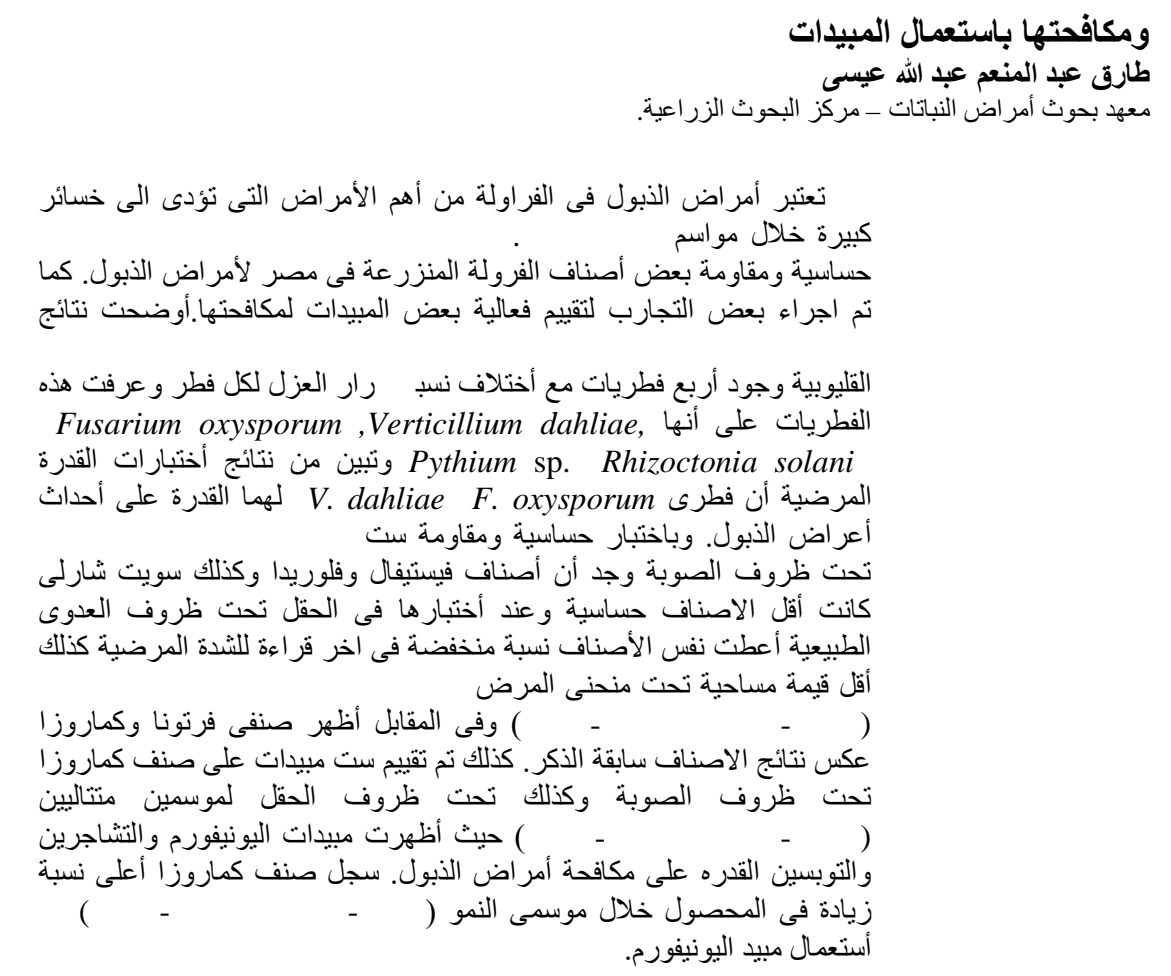

